\title{
MUCOSAL LEISHMANIASIS (“ESPUNDIA”) RESPONSIVE TO LOW DOSE OF N-METHYL GLUCAMINE (GLUCANTIME ®) IN RIO DE JANEIRO, BRAZIL
}

\author{
Manoel Paes de OLIVEIRA-NETO(1), Marise MATTOS(1), Claude PIRMEZ(2), Octavio FERNANDES(3), Sylvio Celso GONÇALVES-COSTA(4),
} Celeste de Freitas Silva de SOUZA(4) \& Gabriel GRIMALDI JUNIOR(5)

\begin{abstract}
SUMMARY
Response to treatment with antimonial drugs varies considerably depending on the parasite strain involved, immune status of the patient and clinical form of the disease. Therapeutic regimens with this first line drug have been frequently modified both, in dose and duration of therapy. A regimen of $20 \mathrm{mg} / \mathrm{kg} /$ day of pentavalent antimony $\left(\mathrm{Sb}^{5+}\right)$ during four weeks without an upper limit on the daily dose is currently recommended for mucosal disease ("espundia"). Side-effects with this dose are more marked in elderly patients, more commonly affected by this form of leishmaniasis. According to our experience, leishmaniasis in Rio de Janeiro responds well to antimony and, in cutaneous disease, high cure rates are obtained with $5 \mathrm{mg} / \mathrm{kg} / \mathrm{day}$ of $\mathrm{Sb}^{5+}$ during 30 to 45 -days. In this study a high rate of cure (91.4\%) employing this dose was achieved in 36 patients with mild disease in this same geographic region. Side-effects were reduced and no antimony refractoriness was noted with subsequent use of larger dose in patients that failed to respond to initial schedule.
\end{abstract}

KEYWORDS: Mucosal leishmaniasis; Leishmania (Viannia) braziliensis; Antimony; Therapy.

\section{INTRODUCTION}

Rio de Janeiro state located in southeast Brazil, is an endemic area of Leishmania (Viannia) braziliensis infection. Mucosal leishmaniasis (ML) is a dreaded late consequence of cutaneous leishmaniasis due to the serious esthetic and functional sequel that may occur in severe cases. Although incidence of mucosal disease is low (perhaps less than $5 \%{ }^{16}$ ), treatment is generally more difficult than for cutaneous cases and only two cases of self-healing mucosal disease have been reported ${ }^{21}$. The drug of choice for treatment of ML is $\mathrm{Sb}^{5+}$ with the dose of $20 \mathrm{mg} / \mathrm{kg} / \mathrm{day}$ during four weeks ${ }^{17,23,34,36}$. Some authors believe that severity of the disease may impair the efficacy of $\mathrm{Sb}^{5+}$ compounds ${ }^{19}$. It has been demonstrated that some Leishmania isolates are innately more susceptible to antimony than others ${ }^{13}$. This seems to be the case of Leishmania parasites present in Rio de Janeiro, where high cure rates for cutaneous disease were obtained with low doses and even intralesional therapy ${ }^{28-31}$. ML in the state of Rio de Janeiro is present as a mild to moderate disease, with a great number of cases restricted to the nose. The disfiguring, destructive lesions commonly associated with this form of leishmaniasis are, nowadays, rarely seen. Mucosal cases are more frequent in the fifth and sixth decades of life as are side effects of antimonial therapy $y^{1,2,7,8,14,15,18}$. For this reason and the fact that the majority of patients studied here presented mild disease it was decided to observe their therapeutical responsiveness to low $\mathrm{Sb}^{5+}$ dose.

\section{METHODS}

Patients: Patients with mild to moderate ML (see definition below) with no age limit were eligible for the study when at least four of the following five criteria were present: (a) compatible clinical lesions and disease history; (b) a positive leishmanin skin test. Leishmanin was provided by Instituto de Ciências Biológicas da Universidade Federal de Minas Gerais ${ }^{26}$ and considered positive when the diameter of induration was equal to or greater then $5 \mathrm{~mm}$; (c) suggestive histopathology; (d) negative tests for other diseases that may affect the oronasal mucous membranes notably leprosy, paracoccidioidomycosis and syphilis; (e) demonstration of leishmania in cultures, histopathology and/or PCR analysis. Exclusion criteria were pregnancy, known or suspected allergy to $\mathrm{Sb}^{5+}$ and use of $\mathrm{Sb}^{5+}$, amphotericin $\mathrm{B}$ or ketoconazole in the last six months before the study. Patients were recruited from the spontaneous demand at the leishmaniasis out-patient unit, Evandro Chagas' Hospital, Oswaldo Cruz Foundation. Dermatologic examination included the upper respiratory/digestive mucosae evaluation using an optical fibroscope (Storz, Mainz, Germany). Anterior rhinoscopy was performed for all patients. Patients presenting lesions of the oral mucosa were submitted to endoscopic examination searching for extension of the lesions to the pharynx or larynx. The level of severity of ML was defined according the criteria suggested by LLANOS-CUENTAS et al. ${ }^{20}$ : mild disease when only the nasal mucosa is affected with symptoms

(1) Hospital Evandro Chagas, Fundação Oswaldo Cruz, Rio de Janeiro, RJ, Brasil.

(2) Depto. de Bioquímica e Biologia Molecular, Instituto Oswaldo Cruz, Fundação Oswaldo Cruz, Rio de Janeiro, RJ, Brasil.

(3) Depto. de Medicina Tropical, Instituto Oswaldo Cruz, Fundação Oswaldo Cruz, Rio de Janeiro, RJ, Brasil.

(4) Departamento de Protozoologia, Instituto Oswaldo Cruz, Fundação Oswaldo Cruz, Rio de Janeiro, RJ, Brasil.

(5) Depto. de Imunologia, Instituto Oswaldo Cruz, Fundação Oswaldo Cruz, Rio de Janeiro, RJ, Brasil.

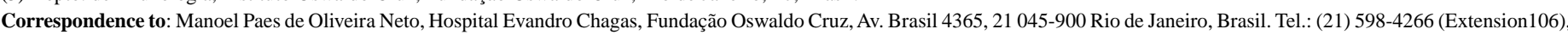
Fax: (21) 590-9988. e-mail: onetohec@ fiocruz.br 


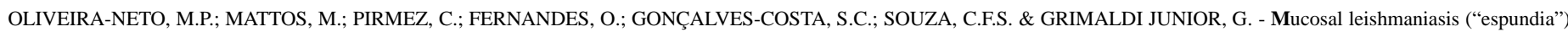
responsive to low dose of N-methyl glucamine (Glucantime ${ }^{\circledR}$ ) in Rio de Janeiro, Brazil. Rev. Inst. Med. trop. S. Paulo, 42(6):321-325, 2000.

confined to the nose (obstruction, bleeding) and moderate disease when two or more mucosal sites are affected, with nasal symptoms plus odinophagia and/or dysphonia and no or mild respiratory distress.

Study design: The study was non-comparative, open, randomized and was designed to assess the value of $\mathrm{Sb}^{5+}$ low doses in the clinical management of ML patients.

Treatment regimen, evaluation and follow-up of patients: Patients were treated with $\mathrm{N}$-methyl glucamine (Glucantime $\AA$, Rhodia Laboratories, Rhône-Poulenc, France) at the dose of $5 \mathrm{mg} / \mathrm{kg} /$ day of $\mathrm{Sb}^{5+}$ intramuscularly applied during thirty-days. If the lesions did not improve or heal after that period, the same therapy was continued for another 15 days. In an attempt to reduce treatment period, a small group of patients $(\mathrm{N}=4)$ received the same total amount of $\mathrm{Sb}^{5+}$ but with the dose of $15 \mathrm{mg} / \mathrm{kg} /$ day during ten-days. In this case, since the volume to be injected was greater, the intravenous route was used diluting the drug solution in $100 \mathrm{ml}$ of $5 \%$ glucose. Affected mucous membranes were re-examined at the end of therapy, three months, six months and one year after. Yearly examinations were performed during follow-up. Side effects were detected by clinical examination and laboratory tests. The following laboratory tests were performed before therapy, within two weeks and at the end of therapy: electrocardiogram, complete blood count, aminotransferases, amilase, lipase, alkaline phosphatase, bilirrubin (total and fractions), blood urea nitrogen, creatinin and urinalysis.

Biopsies, histopathology and cultures: Biopsies were performed utilizing proper forceps preferably on palate and nasal mucosa. No biopsies were performed on cavum and pharynx. In two patients a biopsy of epiglottis was possible and a fragment of a maxillary sinus lesion was obtained by surgery. Topical anesthesia with $1 \%$ Neo-tutocaine was employed for nasal mucosa and local anesthesia for palate lesions. Biopsy specimens were processed for paraffin embedding, H\&E stain and culture in special modified Schneider's medium ${ }^{10}$.

PCR analysis: Genomic DNA was extracted from biopsy fragments using an anion-exchange chromatography spin-column following the manufacture's instructions (Pharmacia, Upsalla, Sweden). Final DNA pellet was resuspended in $20 \mu \mathrm{l}$ of $10 \mathrm{mM}$ Tris- $\mathrm{HCl} \mathrm{pH} 8.0 / 1 \mathrm{mM}$ EDTA $\mathrm{pH} 8.0$, and stored frozen at $-20{ }^{\circ} \mathrm{C}$ until use. A hot-start PCR was performed using oligonucleotides that anneal to the origin of replication of both strands of the minicircle molecules as previously described ${ }^{32}$.

Definition of cure: Cure was defined considering the following clinical criteria: healing of the lesions with disappearance of edema, infiltration, induration or other inflammatory signs and scarring or epithelization of ulcerative lesions. We considered as treatment failure only those cases showing inflammatory alterations after 45 days of therapy.

\section{RESULTS}

Clinical characteristics of patients: A total of 36 patients were enrolled for the study. Clinically, nasal mucosa lesions were characterized by diffuse infiltration, with a granular surface and ulceration mainly of the nasal septum and inferior cornet. Mucosa of both soft and hard palate presented diffuse infiltration with an irregular and bulged surface, classically compared to a cobbled street. The uvula was frequently compromised and the posterior wall of pharynx showed similar lesions. In the larynx, lesions frequently affected the epiglottis, which was oedematous and hyperemic due to diffuse infiltration, a process that results in a hoarse and weak voice. The majority of patients were in the $5^{\text {th }}$ and $6^{\text {th }}$ decades of life and presented long lasting disease. Leishmanin skin test was positive in all patients usually showing strong reactions. (Table 1).

Table 1

General clinical characteristics

\begin{tabular}{ll}
\hline Total number of patients & 36 \\
Males & 22 \\
Females & 14 \\
\hline Mean age (years) \pm SD & $57.6 \pm 15.2$ \\
Median & 60 \\
\hline Mean duration of disease (months) \pm SD & $127.6 \pm 118.6$ \\
Median & 96 \\
\hline LST $(\mathrm{mm}), \pm$ SD & $55.5 \pm 22.6$ \\
Median & 55 \\
\hline
\end{tabular}

Half of the patients had only one mucosal site affected and, in this case, always located at the nose. The other half presented 2, 3 or 4 sites affected (Table 2). Nasal mucosa lesion was detected in all cases, the other lesion sites being the palate, pharynx, larynx and cavum. One patient presented lesions in maxillary sinus (Table 3).

Table 2

Characteristics of mucosal disease

\begin{tabular}{ccc}
\hline No. of mucosal sites affected & No. of patients & $\%$ \\
\hline 1 & 18 & 50.0 \\
2 & 9 & 25.0 \\
3 & 6 & 16.6 \\
4 & 3 & 8.3 \\
\hline
\end{tabular}

Table 3

Location of the mucosal lesions

\begin{tabular}{lcc}
\hline Mucosal location & No. of patients & $\%$ \\
\hline Nasal & 36 & 100 \\
Palate & 14 & 38.8 \\
Pharynx & 10 & 27.7 \\
Larynx & 7 & 19.4 \\
Cavum & 4 & 11.1 \\
Maxillary sinus & 1 & 2.7 \\
\hline
\end{tabular}

Biopsies, histopathological findings, cultures and PCR analysis: Thirty-one patients were submitted to mucosal biopsies. Histopathological findings included a mixed inflammatory infiltrate with granuloma formation in all cases, but amastigotes were present in only five cases. Culture was positive in 16 cases, negative in seven and there was a high rate of culture contamination ( 8 cases $-22.2 \%$ ), a frequent 
event when mucosal samples are cultivated in vitro. On the other hand, demonstration of Leishmania DNA at the site of lesion using PCR analysis was possible in 29 patients showing $79.3 \%$ of positive results (Table 4).

Table 4

Results of histopathology, culture and PCR analysis

\begin{tabular}{lcc}
\hline Test & $\begin{array}{c}\text { \# Positive/ } \\
\text { total examined }\end{array}$ & $\%$ \\
\hline Histopathology* & $5 / 31$ & 16.1 \\
Culture & $16 / 31$ & 51.6 \\
PCR & $23 / 29$ & 79.3 \\
\hline
\end{tabular}

*Histopathology was considered positive when amastigotes were detected on pathological examination of sections.

Response to therapy: One patient did not return for follow-up and was withdrawn from the study. Thirty-one patients were treated with 5 $\mathrm{mg} / \mathrm{kg} /$ day. Twenty-one patients $(67.7 \%)$ had a good response after 30 days of therapy (Fig.1). Ten patients were not healed after a 30-days period and were therefore treated for 15 more days totalizing a 45-days therapy. Seven of these patients achieved total cure after that period; three were considered treatment failure because of the presence of active lesions at the end of 45 days. These latter patients were further treated with higher doses, finally achieving cure. The patients treated with 15 $\mathrm{mg} / \mathrm{kg} /$ day during 10 days showed a good result (Table 5).

Table 5

Response to therapy

\begin{tabular}{lcccccc}
\hline Dose & Period & $\begin{array}{c}\text { Number of } \\
\text { patients }\end{array}$ & Cure & $\%$ & Failure & $\%$ \\
\hline $5 \mathrm{mg} / \mathrm{kg} /$ day & 30 -days & 21 & 21 & 100.0 & 0 & 0 \\
$5 \mathrm{mg} / \mathrm{kg} /$ day & 45 -days & 10 & 7 & 70.0 & 3 & 30 \\
$15 \mathrm{mg} / \mathrm{kg} /$ day & 10 -days & 4 & 4 & 100.0 & 0 & 0 \\
Total & & 35 & 32 & 91.4 & 3 & 8.5 \\
\hline
\end{tabular}

Side-effects: Side effects were noted in 25 of the 35 patients $(71.4 \%)$. These side effects were mild in the majority of patients, being more intense in the four patients who received the schedule of $15 \mathrm{mg} / \mathrm{kg} /$ day during 10-days. The most common side-effects noted were: arthralgias (16 patients $-45.7 \%)$, astenia (13 patients $-37.1 \%)$, mialgias ( 10 patients $-27.7 \%$ ), nausea and vomiting (7 patients $-20 \%$ ), alterations in electrocardiogram - increased QT interval, arrhythmia, extrasystoles, diffuse alterations in repolarization (7 patients $-20 \%$ ), hematological abnormalities - eosinophilia, leukopenia, decreased hematocrit - (6 patients $-17.1 \%$ ), local pain at the site of the injection (6 patients $17.1 \%$ ). In five patients (14.2\%) worsening of lesions was noted at the first injections. Four patients $(11.4 \%)$ presented fever at the beginning of therapy. Two cases developed herpes zoster and three presented herpes simplex by the end of therapy.

Elevation of aminotransferase levels was noted in two patients and raised amilase and lipase in one patient. These three patients received the dose of $15 \mathrm{mg} / \mathrm{kg} /$ day during 10-days.
Follow-up and sequels: Twenty-eight patients who responded to $5 \mathrm{mg} / \mathrm{kg} /$ day and treated for 30 or 45 -days were followed for periods up to seven years. Eleven were followed-up from one to three years; ten from three to five years; seven from five to seven years. The four patients treated with $15 \mathrm{mg} / \mathrm{kg} /$ day during 10 days were followed for three years. No relapse was observed during the follow-up period. The most common sequel was perforation of nasal septum, present in 25 patients. Other sequel more rarely found was uvula destruction in five patients. One patient showed perforation of the nose skin and the patient with extension of the lesions to maxillary sinus presented destruction of orbit's floor.

\section{DISCUSSION}

Leishmaniasis is really a complex disease with a great number of possible combinations of different leishmanial syndromes, parasite species involved and diverse epidemiological patterns in many geographic areas of prevalence of infection. Such combinations result in different clinical presentations, easiness of diagnosis and response to therapy ${ }^{16}$. This study focus on the therapeutical significance of a low antimonial dose in a non comparative fashion, since the efficacy of a $20 \mathrm{mg} / \mathrm{kg} /$ day dosage is well-established ${ }^{3,7,21,25,36}$.

ML, an hyperergic, invasive, ulcerative form of leishmaniasis that progresses in the absence of any apparent cellular defect, is most frequently associated with Leishmania (Viannia) braziliensis. In our study area cutaneous and mucosal disease is caused, so far, exclusively by this species ${ }^{10,11}$. The clinical picture of ML today is quite different from the mutilating cases so frequently seen in the beginning of the century. Such difference may be explained by the difficulty in diagnosis and lack of specific treatment in those early days. The presence of such destructive and menacing disease justified an aggressive therapy employing high doses of antimony. Even nowadays with the increased knowledge about the disease, diagnostic facilities and routine examination of mucous membranes, ML is generally considered very resistant to antimonial therapy and unresponsive cases have been described ${ }^{6,24,27,33}$. The group of patients studied in this paper presented a mild to moderate mucosal disease, with scanty leishmanial organisms and a tuberculoid response at the lesion. In addition, all patients presented a strong cell-mediated immunity (as demonstrated by the high response to leishmanin skin test) and were responsive to a low dosage of $\mathrm{Sb}^{5+}$. This level of response to therapy was different from that described for patients presenting ML in other endemic areas ${ }^{6,11,17,22,36}$. The good result observed in our patients might be related with a non refractoriness of the parasite strain causing the disease and/or distinct host response to this particular parasite. There were significant differences in susceptibility to $\mathrm{Sb}^{5+}$ among clones of a single isolate obtained from an untreated patient ${ }^{13}$. Resistance to $\mathrm{Sb}^{5+}$ exists among Leishmania strains in nature and some isolates are innately less or more susceptible to this drug than others ${ }^{13}$.

Because of differences in virulence and in the response to chemotherapeutic agents among the various Leishmania species or strain variants, correct parasite identification is essential. Studies using several DNA based methods have shown the wide diversity of parasites within L.(V.) braziliensis ${ }^{5}$. Genetic variation is extensive with some clones widely distributed and others seemingly unique and localized to a particular endemic focus. These studies should provide the basis to monitor transmission and for disease control ${ }^{4,5}$. Future research using molecular biology should aim to identify and follow Leishmania types in nature 


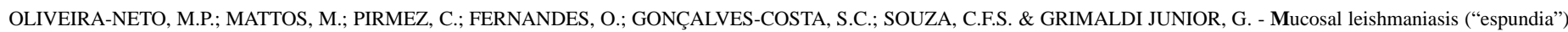
responsive to low dose of N-methyl glucamine (Glucantime ${ }^{\circledR}$ ) in Rio de Janeiro, Brazil. Rev. Inst. Med. trop. S. Paulo, 42(6):321-325, 2000.

and correlate genetic typing with important clinical characteristics such as virulence, pathogenicity, drug resistance and antigenic variation ${ }^{4}$. Genetic or racial differences also may play a role in determining some of the variations observed among patients in the course of the infection ${ }^{35}$.

The median age of patients studied was 60 -years. ML in elderly patients is usually associated with internal diseases frequent in aged people, such as hypertension, diabetes, arthrosis among others that may increase the severity of the disease and/or side-effects during chemotherapy. In such patients the use of lower doses is desirable since the toxic effects of antimony are less pronounced and, consequently, the adhesion to therapy is greater. No antimony refractoriness has increased in the three patients that did not responded to the low dose. These patients responded well to the dose of $20 \mathrm{mg} / \mathrm{kg} /$ day during four weeks. Also, the use of a dose of $5 \mathrm{mg} / \mathrm{kg} /$ day reduced significantly the price of treatment. The use of a dose of $15 \mathrm{mg} / \mathrm{kg} /$ day during ten days, resulting in the same amount of antimony applied at the dose of $5 \mathrm{mg} / \mathrm{kg} /$ day during 30-days, was also effective but with more severe side-effects and with the inconvenient of intravenous injection since the volume to be injected was too great for intramuscular therapy. Elevation of aminotransferase, amilase and lipase plasma levels was noted only with the dose of $15 \mathrm{mg} / \mathrm{kg} /$ day. It is important to emphasize that no relapses were noted during the follow-up which extended from one to seven years.

In conclusion we may say that the dose of $5 \mathrm{mg} / \mathrm{kg} / \mathrm{day}$ of $\mathrm{Sb}^{5+}$ during 30 or 45 days seems to be effective for mucosal leishmaniasis. Sideeffects, although frequently observed, were always of slight intensity and very well tolerated by the patients. In case of failure, this initial low dose therapy apparently do not impair the responsiveness of the patients to the use of subsequent larger dose. We think that a low dose could be the first line of treatment, at least for patients of the same geographic area here reported or even in cases of mild ML occurring in other endemic area.

\section{RESUMO}

\section{Leishmaniose mucosa ("espundia") respondendo a baixa dose de N-metil-glucamina (Glucantime ${ }^{\circledR}$ ) no Rio de Janeiro, Brasil}

A resposta de pacientes com leishmaniose ao tratamento antimonial pode variar em função de fatores como a cepa do parasito envolvido, estado imunológico do paciente e a forma clínica da doença. Os esquemas terapêuticos com antimônio pentavalente $\left(\mathrm{Sb}^{5+}\right)$ têm sido frequentemente modificados quanto à dose e duração da terapia. Os efeitos colaterais observados com o uso de $20 \mathrm{mg} / \mathrm{kg} /$ dia de $\mathrm{Sb}^{5+}$ durante quatro semanas (dose recomendada para o tratamento da forma mucosa) são mais acentuados em pacientes idosos, os mais afetados pela forma mucosa (espundia) da doença. Nossa experiência demonstra que a forma cutânea ocorrendo no Rio de Janeiro responde muito bem ao tratamento com a dose de $5 \mathrm{mg} / \mathrm{kg} / \mathrm{dia}$ de $\mathrm{Sb}^{5+}$ durante 30 ou 45 dias. Neste estudo foi obtida elevada eficácia $(91,4 \%)$ com o mesmo regime terapêutico em 36 pacientes com espundia (que evoluem, contudo, com lesão crônica menos destrutiva do que o observado em outras áreas endêmicas) procedentes desta região. Os efeitos colaterais foram reduzidos, não havendo também qualquer resistência ao emprego de doses maiores nos casos que não responderam ao tratamento inicial.

\section{ACKNOWLEDGEMENTS}

This study was supported by FAPERJ (Fundação de Amparo à Pesquisa no Rio de Janeiro), process $n^{\circ}$ E-26/170-825/95.

The authors thank João Moreira, M.D., for evaluation of mucosal lesions.

\section{REFERENCES}

1. ANTEZANA, G.; ZEBALlOS, R.; MENDOZA, C. et al. - Electrocardiographic alterations during treatment of mucocutaneous leishmaniasis with meglumine antimoniate and allopurinol. Trans. roy. Soc. trop. Med. Hyg., 86: 31-33, 1992.

2. BALZAN, M. \& FENECH, F. - Acute renal failure in visceral leishmaniasis treated with sodium stibogluconate. Trans. roy. Soc. trop. Med. Hyg., 86: 515-516, 1992.

3. BRYCESON, A.D.M. - Leishmaniasis. In: COOK, G.C., ed. Manson's tropical diseases. 20. ed. Philadelphia, W.B. Saunders, 1996. p. 1213-1245.

4. CUPOLILLO, E.; MOMEM, H. \& GRIMALDI JR., G. - Genetic diversity in natural populations of New World Leishmania. Mem. Inst. Oswaldo Cruz, 93: 663-668, 1998.

5. CUPOLILLO, E.; MEDINA-ACOSTA, E.; NOYES, H.; MOMEM, H. \& GRIMALDI JR., G. - A revised classification for Leishmania and Endotrypanum. Parasit. today, 16: $142-144,2000$.

6. FALCOFF, E.; TARANTO, N.J.; REMONDEGUI, C.E. et al. - Clinical healing of antimony-resistant cutaneous or mucocutaneous leishmaniasis following the combined administration of interferon-gamma and pentavalent antimonial compounds. Trans. roy. Soc. trop. Med. Hyg., 88: 95-97, 1994.

7. FRANKE, E.D.; WIGNALL, F.S.; CRUZ, M.E. et al. - Efficacy and toxicity of sodium stibogluconate for mucosal leishmaniasis. Ann. intern. Med., 113: 934-940, 1990.

8. GASSER, R.A.; MAGILL, A.J.; OSTER, C.N. et al. - Pancreatitis induced by pentavalent antimonial agents during treatment of leishmaniasis. Clin. infect. Dis., 18: 83-90, 1994

9. GReVElinK, S.A. \& LERnER, E.A. - Leishmaniasis. J. Amer. Acad. Derm. 34: $257-272,1996$.

10. GRIMALDI JR, G.; TESH, R.B. \& MCMAHON-PRATT, D. - A review of the geographic distribution and epidemiology of leishmaniasis in the New World. Amer. J. trop. Med. Hyg., 41: 687-725, 1989.

11. GRIMALDI JR., G. \& TESH, R.B. - Leishmaniases of the New World: current concepts and implications for future research. Clin. Microbiol. Rev., 6: 230-250, 1993.

12. GROGL, M.; ODUOLA, A.M.J.; CORDERO, L.D.C. \& KYLE, D.E. - Leishmania ssp.: development of pentostan-resistant clones in vitro by discontinuous drug exposure. Exp. Parasit., 69: 78-90, 1989.

13. GROGL, M.; THOMASON, T.N. \& FRANKE, E.D. - Drug resistance in leishmaniasis its implication in systemic chemotherapy of cutaneous and mucocutaneous disease. Amer. J. trop. Med. Hyg., 47: 117-126, 1992.

14. HEPBURN, N.C. - Thrombocytopenia complicating sodium stibogluconate therapy for cutaneous leishmaniasis [letter]. Trans. roy. Soc. trop. Med. Hyg., 87: 691, 1993.

15. HEPBURN, N.C.; SIDDIQUE, I.; HOWIE,, A.F.; BECKET, G.J. \& HAYES, P.C. Hepatotoxicity of sodium stibogluconate in leishmaniasis [letter]. Lancet, 342: 238239, 1993

16. HERWALDT, B.L. - Leishmaniasis. Lancet, 354: 1191-1199, 1999. 


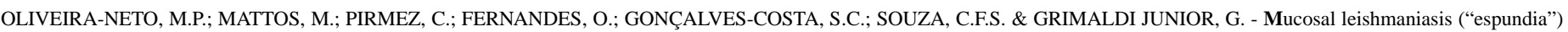
responsive to low dose of N-methyl glucamine (Glucantime ${ }^{\circledR}$ ) in Rio de Janeiro, Brazil. Rev. Inst. Med. trop. S. Paulo, 42(6):321-325, 2000.

17. HERWALDT, B.L. \& BERMAN, J.D. - Recommendations for treating leishmaniasis with sodium stibogluconate (Pentostam) and review of pertinent clinical studies. Amer. J. trop. Med. Hyg., 46: 296-306, 1992.

18. HORBER, F.F.; LERUT, J. \& JAEGER, P. - Renal tubular acidosis, a side effect of treatment with pentavalent antimony [letter]. Clin. Nephrol., 36: 213, 1991.

19. LLANOS-CUENTAS, A. - Tratamiento de leishmaniasis mucosa: analisis de los fatores asociados con la respuesta terapeutica a los antimoniales pentavalentes. Lima, 1991. (Thesis - Escuela de Post-Grado "Victor Alzamora Castro" de la Universidad Peruana Cayetano Heredia).

20. LLANOS-CUENTAS, A.; ECHEVARRIA, J.; CRUZ, M. et al. - Efficacy of sodium stibogluconate alone and in combination with allopurinol for treatment of mucocutaneous leishmaniasis. Clin. infect. Dis., 25: 677-684, 1997.

21. MARSDEN, P.D. - Mucosal leishmaniasis (“Espundia”, Escomel, 1911). Trans. roy. Soc. trop. Med. Hyg., 80: 859-876, 1986.

22. MARSDEN, P.D. - Mucocutaneous leishmaniasis. Brit. med. J., 301: 656-657, 1990.

23. MARSDEN, P.D. - Mucosal leishmaniasis due to Leishmania (Viannia) braziliensis L(V)b in Três Braços, Bahia-Brazil. Rev. Soc. bras. Med. trop., 27: 93-101, 1994

24. MARSDEN, P.D.; LESSA, H.A.; OLIVEIRA, M.R. et al. - Clinical observations of unresponsive mucosal leishmaniasis. Amer. J. trop. Med. Hyg., 59: 543-545, 1998.

25. MARSDEN, P.D.; LlANOS-CUENTAS, E.A.; LAGO, E.L. et al. - Human mucocutaneous leishmaniasis in Três Braços, Bahia, Brasil. An area of Leishmania braziliensis braziliensis transmission. III. Mucosal disease presentation and initial evolution. Rev. Soc. bras. Med. trop., 17: 179-186, 1984.

26. MELO, M.N.; MAYRINK, W.; COSTA, C.A. et al. - Padronização do antígeno de Montenegro. Rev. Inst. Med. trop. S. Paulo., 19: 161-164, 1977.

27. NONATA, R.; SAMPAIO, R. \& MARSDEN, P.D. - Mucosal leishmaniasis unresponsive to glucantime therapy successfully treated with AmBisome. Trans. Roy. Soc. trop. Med. Hyg., 91: 77, 1997.
28. OLIVEIRA-NETO, M.P.; SCHUBACH, A.; ARAUJO, M.L. \& PIRMEZ, C. - High an low doses of antimony $\left(\mathrm{Sb}^{v}\right)$ in American Cutaneous Leishmaniasis. A five-years follow-up study of 15 patients. Mem. Inst. Oswaldo Cruz, 91: 207-209, 1996.

29. OLIVEIRA-NETO, M.P.; SCHUBACH, A.; MATTOS, M.; GONCALVES-COSTA, S.C \& PIRMEZ, C. - A low-dose antimony treatment in 159 patients with American cutaneous leishmaniasis: extensive follow-up studies (up to 10 years). Amer. J. trop. Med. Hyg., 57: 651-655, 1997.

30. OLIVEIRA-NETO, M.P.; SCHUBACH, A.; MATTOS, M.; GONÇALVES-COSTA, S.C \& PIRMEZ, C. - Intralesional therapy of American cutaneous leishmaniasis with pentavalent antimony in Rio de Janeiro, Brazil - an area of Leishmania (V.) braziliensis transmission. Int. J. Derm., 36: 463-468, 1997.

31. OLIVEIRA-NETO, M.P.; SCHUBACH, A.; MATTOS, M.; GONÇALVES-COSTA, S.C. \& PIRMEZ, C. - Treatment of American cutaneous leishmaniasis: a comparison between low dosage $(5 \mathrm{mg} / \mathrm{kg} /$ day $)$ and high dosage $(20 \mathrm{mg} / \mathrm{kg} /$ day $)$ antimony regimens. Path. Biol., 45: 496-499, 1997.

32. PIRMEZ, C.; TRAJANO, V.; OLIVEIRA-NETO, M. P. et al. - Use of PCR in diagnosis of human American tegumentary leishmaniasis in Rio de Janeiro, Brazil. J. clin. Microbiol., 37: 1819-1823, 1999

33. ROCHA, R.A.A.; SAMPAIO, R.N.; GUERRA, M. et al. - Apparent Glucantime failure in five patients with mucocutaneous leishmaniasis. J. trop. Med. Hyg., 83: 131 $139,1980$.

34. SAENZ, R.E.; DE RODRIGUEZ, C.G.; JOHNSON, C.M. \& BERMAN, J.D. - Efficacy and toxicity of pentostam against Panamanian mucosal leishmaniasis. Amer. J. trop. Med. Hyg., 44: 394-398, 1991.

35. WALTON, B.C. \& VALVERDE, L.C. - Racial differences in espundia. Ann. trop. Med. Parasit., 73: 23-29, 1979.

36. WORLD HEALTH ORGANIZATION - The Leishmaniasis. Wld. Hlth. Org. techn. Rep. Ser., 793: 59-62, 1990.

Received: 15 May 2000

Accepted: 17 July 2000 